\title{
Potensi Konflik Kepentingan dalam Pendirian Badan Hukum Perorangan Pasca Revisi Undang-Undang Perseroan Terbatas dalam Omnibus Law
}

\author{
Febri Jaya ${ }^{\circledR}$ \\ Fakultas Hukum Universitas Internasional Batam \\ E-mail Korespondensi: febri.jaya@uib.edu / best.1992@yahoo.com
}

\begin{abstract}
The need for employment in Indonesia continues to increase every year, so there is naturally a concern that there will be conditions where the need for employment is more than the available employment opportunities. Therefore, several actions have been taken by the executive and legislature to anticipate these conditions, one of which is by facilitating the establishment of a limited liability company which previously had to be established by 2 (two) or more people to only 1 (one) person with certain conditions regulated in Law Number 11 of 2020 concerning Job Creation. In practice, there are many internal disputes related to conflicts of interest in a limited liability company established by 2 (two) or more people, even though when it is founded by 2 (two) or more people, supervision of the management of a limited liability company will certainly be better than that of a limited liability company established. by 1 (one) person. This study discusses the potential for a conflict of interest in a limited liability company established by 1 (one) person who also serves as the only member of the Director in the company.
\end{abstract}

Keywords: Limited Liability Company, Conflict of Interest, Job Creation.

\begin{abstract}
Abstrak
Kebutuhan lapangan kerja di Indonesia terus naik setiap tahunnya, sehingga sudah sewajarnya terdapat kekhawatiran terjadi kondisi dimana kebutuhan lapangan kerja lebih banyak dari lapangan kerja yang tersedia. Oleh karena itu beberapa tindakan telah dilakukan oleh eksekutif dan legislatif untuk mengantisipasi kondisi tersebut, salah satunya dengan dipermudahnya pendirian perseroan terbatas yang sebelumnya harus didirikan oleh 2 (dua) orang atau lebih menjadi dapat didirikan oleh 1 (satu) orang saja dengan persyaratan tertentu yang diaturdalam Undang-Undang Nomor 11 tahun 2020 tentang Cipta Kerja. Pada prakteknya, banyak terjadi sengketa internal terkait konflik kepentingan dalam perseroan terbatas yang didirikan 2 (dua) orang atau lebih, padahal dengan didirikan oleh 2 (dua) orang atau lebih, pengawasan terhadap pengurusan perseroan terbatas tentu akan lebih baik dibandingkan dengan perseroan terbatas yang didirikan oleh 1 (satu) orang. Penelitian ini membahas mengenai potensi terjadinya konflik kepentingan dalam suatu persroan terbatas yang didirikan oleh 1 (satu) orang yang juga menjabat sebagai satu-satunya anggota Direktur dalamperseroan tersebut.
\end{abstract}

Kata kunci: Perseroan Terbatas, Konflik Kepentingan, Cipta Kerja.

Copyright@2021KosmikHukum. All rights reserved.

\section{Pendahuluan}

Kebutuhan lapangan kerja di Indonesia terus naik setiap tahunnya, sehingga sudah sewajarnya terdapat kekhawatiran terjadi kondisi dimana kebutuhan lapangan kerja lebih banyak dari lapangan kerja yang tersedia. Oleh karena itu beberapa tindakan telah dilakukan oleh eksekutif dan legislatif untuk mengantisipasi kondisi tersebut, salah satunya dengan dipermudahnya pendirian perseroan terbatas yang sebelumnya harus didirikan oleh 2 (dua) orang atau lebih menjadi dapat didirikan oleh 1 (satu) orang saja dengan persyaratan tertentu yang diatur dalam Undang-Undang Nomor 11 tahun 2020 tentang Cipta Kerja (selanjutnya disebut UU Cipta Kerja). 
Kosmik Hukum Vol. 21 No. 2 (2021): 115-123

E-ISSN: 2655-9242 | P-ISSN: 1411-9781

DOI: 10.30595/kosmikhukum.v21i2.10310

UU Cipta Kerja yang juga dikenal dengan istilah Omnibus Law diharapkan mampu menyerap sebanyak-banyaknya tenaga kerja di Indonesia, hal ini mengingat semakin kompetitifnya persaingan yang disebabkan tuntutan ekonomi global. Peraturan-peraturan pun dibuat sedemikian rupa agar memberikan kemudahan dan perlindungan kepada usaha mikro, kecil dan menengah. Perubahan mengenai Undang-Undang Nomor 40 Tahun 2007 tentang Perseroan Terbatas (untuk selanjutnya disebut UU Perseroan Terbatas) diatur pada pasal 109 UU Cipta Kerja yang terletak dalam BAB VI mengenai Kemudahan Berusaha dalam bagian kelima tentang Perseroan Terbatas.

Sebenarnya pendirian perusahaan berbadan hukum oleh 1 (satu) orang telah lama diimplementasikan diberbagai negara seperti Singapura, Malaysia, Belanda dan lainnya, namun mengingat di Indonesa baru belakangan ini diatur, maka masih banyak menuai pro dan kontra dari para akademisi dan praktisi. Pada faktanya banyak terjadi sengketa internal terkait konflik kepentingan dalam perseroan terbatas yang didirikan 2 (dua) orang atau lebih yang masuk sampai ke ranah pengadilan, sehingga tidak sedikit yang berpendapat pendirian perseroan terbatas oleh 1 (satu) orang sangat berpotensi menimbulkan konflik kepentingan, apalagi jika pemegang saham tersebut juga menjabat sebagai satu-satunya anggota direksi dalam perseroan terbatas, penerapan prinsip-prinsip good corporate governance pun disebut akan menjadi lebih sulit dilakukan.

Pendirian perseroan terbatas perorangan menimbulkan banyak pro dan kontra, pada pihak yang mendukung berargumentasi bahwa sudah saatnya Indonesia mempunyai suatu badan hukum yang didirikan oleh perorangan seperti di negara-negara lainnya sedangkan yang kontra berargumen peraturan tersebut tidak dibuat dengan seksama sehingga berpotensi menimbulkan masalah hukum lainnya dan dapat menumbulkan oleh pihak lain yang mempunai hubungan hukum dalam kegiatan bisnis dengan perseroan tersebut. Oleh karena itu, Penulis tertarik untuk meneliti mengenai potensi terjadinya konflik kepentingan pada perseroan terbatas yang didikan oleh 1 (satu) orang yang juga menjabat sebagai satu-satunya anggota direksi dalam perseroan.

\section{Rumusan Masalah}

Berdasarkan uraian latar belakang tersebut diatas, penulis merumuskan rumusan masalah yang akan dibahas dalam artikel ini adalah: Apakah pendirian perseroan terbatas oleh satu orang yang juga menjabat sebagai satu-satunya direksi akan berpotensi menimbulkan konfik kepentingan yang dapat merugikan pihak lainnya?

\section{Metode Penelitian}

Penelitian ini dilakukan untuk mengetahui potensi terjadinya konflik kepentingan dalam perseroan terbatas yang didirikan oleh 1 (satu) orang khususnyapemegang saham yang juga menjabat sebagai satu-satunya anggota direksi. Hal ini menjadi penting khsuusnya bagi pihak yang akan mengikatkan diri dalam hubungan bisnis kepada perseroan tersebut, besarnya terjadi potensi konflik kepentingan yang terjadi dalam suatu perseroan terbatas perlu dianalisa karena berpotensi merugikan pihak-pihak yang mempunyai suatu perikatan dengan perseroan tersebut akibat pengelolaan perseroan yang tidak profesional, hal tersebut akan menimbulkan permasalahan mengenai pertanggungjawaban jika terjadi kerugian yang dialami pihak-pihak tersebut akibat kesalahan dalam pengurusan perseroan terbatas oleh direksi. Pada sisi yang lain penuli singin meneliti apakah perseroan terbatas tepat untuk didirikan oleh perorangan mengingat ada beberapa jenus badan usaha lainnya di Indonesia yang mungkin saja bisa leih tepat untuk mengakomodir hal tersebut.

Penelitian di bidang ilmu hukum merupakan hal yang sentral dan harus dilakukan secara terus menerus, oleh karena itu bagaimana cara meneliti suatu hal dalam ilmu hukum menjadi penting, terdapat beberapa metode penelitian dalam ilmu hukum dimana setiap metode akan menghasilkan yang berbeda pula. 
Meuwissen membedakan antara ilmu hukum normatif dan empiris, khusus mengenai ilmu hukum normatif ia menyebut sebagai sesuatu yang bersifat sui generis yang berarti tidak ada bentuk ilmu lain yang dapat dibandingkan dengan ilmu hukum, dimana menurutnya ilmu hukum normatif mempunyai peran sentral dalam pendidikan di universitas. ${ }^{1}$

Oleh sebab itu penelitian ini menggunakan metode penelitian normatif dengan pendekatan undang-undang atau juga dikenal dengan statute approach yang dilakukan dengan cara menelaah undang-undang dan peraturan-peraturan lainnya yang berkaitan dengan pembahasan. ${ }^{2}$ Pendekatan yang digunakan dalam penelitian ini adalah pendekatan perundangundangan (statute approach) dengan menggunakan perangkat hukum positif sebagai dasar awal melakukan analisis. ${ }^{3}$

\section{Hasil dan Pembahasan}

\section{Batasan Kedudukan Perseroan Terbatas Pada Umumnya}

Perseroan terbatas merupakan suatu badan usaha berbadan hukum yang merupakan persekutuan modal dimana harta kekayaan pribadi para sekutunya terpisah dengan modal yang disetornya, artinya para pemegang saham hanya bertanggung jawab sampai sebatas modal yang ia setorkan. ${ }^{4}$ Oleh karena itu, para pemegang saham secara teoritis tidak dapat dimintakan pertanggung jawaban hingga harta pribadi sepanjang tidak ada kesalahan yang secara langsung diperbuatan oleh pemegang saham yang bersangkutan tersebut.

Dalam sejarah perkembangan pengaturan perseroan terbatas berada pada titik stagnan sejak Kitab Undang-Undang Hukum Dagang diberlakukan di Indonesia (Hindia Belanda pada saat itu) pada tahun 1848 berdasarkan asas konkordansi/concordantie beginsel. Perubahan pertama terhadap pengaturan mengenaiperseroan terbatas baru ada pada tahun 1995 dengan diberlakukannya Undang-Undang Nomor 1 Tahun 1995 tentang Perseroan Terbatas, dan 12 (dua belas) tahun kemudian Pemerintah melakukan perubahan kedua dengan diberlakukannya Undang-Undang Nomor 40 Tahun 2007 tentang Perseroan Terbatas menggantikan undangundang sebelumnya. Dua kali perubahan secara kelembagaan peraturan mengenai perseroan terbatasmampu menggambarkan karakter yang bertolak belakang ketika dihadapkan dengan aktivitas ekonomi yang cenderung cair dan dinamis. ${ }^{5}$

Hadirnya UU Cipta Kerja memberikan perubahan beberapa perubahan, salah satunya yaitu dapat didirikannya Perseroan Terbatas oleh 1 (satu) orang. Hal ini berdampak pada diubahnya Pasal 1 angka 1 UU Perseroan Terbatas yang memberikan definisi mengenai Perseroan Terbatas. Berdasarkan Pasal 109 UU Cipta Kerja Pasal 1 angka 1 UU Perseroan Terbatas dirubah menjadi: "Perseroan terbatas yang selanjutnya disebut Perseroan, adalah badan hukum yang merupakan persekutuan modal, didirikan berdasarkan perjanjian, melakukan kegiatan usaha dengan modal dasar yang seluruhnya terbagi dalam saham atau Badan Hukum perorangan yang memenuhi kriteria Usaha Mikro dan Kecil sebagaimana diatur dalam peraturan perundangundangan mengenai Usaha Mikro dan Kecil."

Perubahan tersebut memang harus dilakukan karena dimungkinkannya perseroan terbatas didirikan oleh 1 (satu) orang, namun dalam definisi tersebut urut ebebrapa praktisi hukum terdapat pertentangan antara unsur didirikannya perseroan berdasakan perjanjian dan dimungkinkannya pendirian perseroan terbatas oleh perorangan. Menurut mereka tidak hanya terdapat pertentangan secara grammatikal, secara teoritis dalam suatu perjanjian terdapat asas konsensualisme yang sangat menentukan adanya perjanjian, maka pendirian perseroan terbatas oleh perorangan juga berbenturan dengan asas konsensualisme tersebut. ${ }^{6}$ Namun menurut penulis hal definisi terbaru dari istilah perseroan terbatas yang ada alam UU Cipta Kerja tidaklah

\footnotetext{
Peter Mahmud Marzuki, Pengantar Ilmu Hukum (Jakarta, Prenada Media Group, 2011), 34-35. Ibid, 131.

Johnny Ibrahim, Teori dan Metodologi Penelitian Hukum Normatif, (Malang: Bayumedia, 2008), 302. Tuti Rastuti, Seluk Beluk Perusahaan E Hukum Perusahaan (Bandung, Refika Aditama, 2015), 36-37.

Tri Budiyono, Hukum Perusahaan (Salatiga, Griya Media, 2011), 12.

Agus Yudha Hernoko, Hukum Perjanjian (Jakarta, Prenada Media Group, 2014), 121.
} 
keliru, frasa "atau" dalam definisi tersebut memberikan arti bahwa bahwa hukum perseroan terbatas yang didirikan oleh (dua) orang atau lebih didasarkan pada perjanjian, sedangkan untuk perorangan tidak didasarkan dengan perjanjian.

Sesuai dengan ketentuan Undang-Undang Nomor 40 Tahun 2007 Tentang Perseroan Terbatas, organ dalam perseroan adalah sebagai berikut:

\section{a. Rapat Umum Pemegang Saham;}

Rapat umum pemegang saham (yang selanjutnya disebut RUPS) merupakan salah satu ogan perseroan yang memiliki wewenang yang tidak diberikan kepada organ lainnya yang ditentukan dalam perundang-undangan dan/atau anggaran dasar. Definisi RUPS dalam UU Perseroan terbatas dan UU Cipta Kerja tidak terdapat perbedaan.

RUPS mempunyai wewenang yang tidak diberikan direksi atau dewan komisaris, namun bukan berarti RUPS merupakan organ tertinggi dalam perseroan. Kedudukan RUPS sebagai salah satu organ perseroan adalah sama dengan organ perusahaan yang lain seperti direksi dan dewan komisaris. RUPS, direksi dan dewan komisaris adalah sederajat.7Dengan demikian, tidak dapat dikatakan RUPS lebih tinggi dari direksi dan dewan komisaris. Masing-masing mempunyai posisi dan kewenangan sesuai dengan fungsi dan tanggung jawab yang mereka miliki. 8

\section{b. Direksi;}

Kegiatan perseroan terbatas sehari-harinya diurus oleh direksi, direksi merupakan organ yang bertanggung jawab penuh terkait dengan pengurusan perseroan untuk kepentingan perseroan dan harus sesuai dengan maksud dan tujuan perseroan, oleh karena itu direksi dapat mewakili perseroan baik didalam maupun diluar pengadilan. Definisi direksi dalam UU Perseroan terbatas dan UU Cipta Kerja tidak terdapat perbedaan.

Jika dijabarkan kewenangan direksi antara lain yakni melaksanakan pengurusan yang meliputi pengurusan sehari-hari perseroan, yang mana dalam pengurusan tersebut direksi harus menjalankannya sesuai dengan kepentingan perseroan, maksud dan tujuan perseroan serta sesuai dengan kebijakan yang dipandang tepat. Direksilah satu-satunya organ yang berkapasitas mewakili perseroan, jika dalam suatau perseroan terdapat beberapa angota direksi maka semuanya daapt mewakili perseroan kecuali ditentukan lain dalam anggaran dasar.

\section{c. Dewan Komisaris;}

Pengurusan perseroan terbatas yang dilakukan oleh direksi diawasi oleh dewan komisaris yang bertugas melakukan pengawasan baik secara umum dan/atau khusus sesuai dengan anggran dasar perseroan serta memberikan nasihat atau saran kepada Direksi. Definisi dewan komisaris dalam UU Perseroan terbatas dan UU Cipta Kerja tidak terdapat perbedaan.

Dewan komisaris bertanggung jawab atas tugas dari pengawasan pelaksanaan kegiatan perseroan dimana ia dapat memberikan masukan-masukan kepada direksi untuk kepentingan perseroan, hal ini pun tidak dibatasi untuk direksi saja, namun dewan komisaris jika para pemegang saham menghendaki dapat memberi keterangan-keterangan atau saran untuk menjadi pertimbangan para pemagang saham dalam mengambil keputusan dalam RUPS.

\section{Perubahan Kedudukan Organ dalam Perseroan Terbatas dalam Undang-Undang Nomor 11 Tahun 2020 Tentang Cipta Kerja}

UU Cipta Kerja memberi kemudahan dalam pendirian perseroan terbatas, dimana badan hukum tersebut kini dapat didirikan oleh 1 (satu) orang atau perorangan. Hal tersebut berdasarkan Pasal 7 UU Perseroan Terbatas yang dirubah melalui UU Cipta Kerja. Pada pasal 7 ayat (1) ditentukan bahwa perseroan didirikan oleh 2 (dua) orang atau lebih, namun pengecualiannya terdapat pada pasal 7 ayat (7) huruf d, yang mana kewajiban mendirikan

\footnotetext{
Binoto Nadapdap, Hukum Perseroan Terbatas (Jakarta: Jala Permata Aksara, 2009), 111.
}

8 M. Yahya Harahap, Hukum Perseroan Terbatas (Jakarta: Sinar Grafika, 2009), hlm. 307. 
perseroan terbatas didirikan oleh 2 (dua) orang atau lebih tidak berlaku bagi perseroan terbatas yang memenuhi kriteria untuk usaha Mikro dan Kecil, sebelum menjelaskan lebih lanjut, berikut penjelasan mengenai kriteria usaha Mikro dan Kecil.

\section{a. Usaha Mikro}

Berdasarkan Undang-Undang Nomor 20 Tahun 2008 tentang Usaha Mikro, Kecil dan Menengah (selanjutnya disebut UU UMKM), usaha mikro merupakan usaha produktif yang dimiliki perorangan dan/atau badan usaha perorangan yang memenuhi kriteria yang ditentukan dalam UU UMKM.

Kriteria usaha mikro yakni memiliki kekayaan bersih paling banyak Rp 50.000 .000 (lima puluh juta Rupiah) yang tidak termasuk bangunan dan tanah tempat usaha atau hasilpenjualan tahunannya paling banyak Rp 300.000.000,- (tiga ratus jutaRupiah).

\section{b. Usaha Kecil}

Usaha Kecil sebagaimana dijelaskan dalam UU UMKM meupakan usaha ekonomi produktif yang mandiri atu berdiri sendiri yang dijalankan oleh perorangan atau badan usaha yang bukan merupakan anak perusahaan atau cabang yang dimiliki, dikuasai atau bagian langsung dari Usaha Menengah atau Usaha Besar.

Kriteria usaha kecil yakni memiliki kayaan bersih lebih dari Rp 50.000.000,- (lima puluh juta Rupiah) sampai dengan maksimal Rp 500.000.000,- (lima ratus juta Rupiah) yang tidak termasuk bangunan dan tanah tempat usaha atau hasil penjualan tahunannya lebih dari Rp 300.000.000,- (tiga ratus juta Rupiah) sampai dengan maksimal Rp 2.500.000.000,- (dua miliar lima ratus juta Rupiah).

\section{c. Syarat Pendirian Perseroan Terbatas Perorangan}

Pendirian perseroan terbatas perorangan diatur lebih lanjut dalam Peraturan Pemerintah Nomor 8 Tahun 2021 tentang Modal Dasar Perseroan Serta Pendaftaran Pendirian, Perubahan Dan Pembubbaran Perseroan Yang Memenuhi Kriteria Untuk Usaha Mikro Dan kecil (selanjutnya disebut PP No.8/2021). Berdasarkan Pasal 153 A UU Perseroan Terbatas, perseroan terbatas perorangan dapat didirikan berdasarkan surat pernyataan pendirian yang dibuat dalam bahasa Indonesia, dimana perseroan terbatas tersebut harus memenuhi kriteria usaha mikro dan kecil.

Pasal 1 angka 2 PP No.8/2021 menjelaskan bahwa pernyataan pendirian merupakan format isian untuk pendirian perseroan perorangan secara elektronik, oleh karena itu tidak memerlukan akta pendirian perseroan terbatas yang dibuat dihadapan Notaris. Perseroan perorangan hanya dapat didirikan oleh warga negara indonesia yang berusia paling rendah 17 (tujuh belas) tahun dan cakap hukum. Cakap hukum disini dalam artian yang bersangkutan tidak dinyatakan oleh pengadilan berada diawah pengampuan. Menurut Subekti orang yang dibawah pengampuan ialah orang yang sudah dewasa namun menderita sakit ingatan. ${ }^{9}$

Format isian yang harus diisi memuat keterangan mengenai nama serta tempat kedudukan perseroan terbatas perorangan, jangka waktu berdirinya perseroan, maksud dan tujuan serta kegiatan usaha perseroan, jumlah modal dasar, modal ditempatkan, modal disetor, nilai nominal dan jumlah saham, alamat perseroan dan terakhir data pendiri berupa nama lengkap, tempat dan tanggal lahir, pekerjaan, tempat tinggal, nomor induk kependudukan dan nomor pokok wajib pajak dari pendiri sekaligus direktur dan pemegang saham perorangan.

Perseroan perorangan tersebut akan mendapatkan status badan hukum setelah didaftarkan kepada menteri dan mendapatkan bukti pendaftaran secara elektronik dan perolehan status badan hukumnya akan diumumkan dalam laman resmi direktorat jenderal yang melaksanakan tugas dan fungsi di bidang admintrasi hukum umum pada Kementerian Hukum dan Hak Asasi Manusia.

Subekti. Pokok-Pokok Hukum Perdata (Jakarta, Intermasa, 2008), 56. 
Pada UU Cipta Kerja diatur bahwa pendiri perseroan hanya dapat mendirikan perseroan perorangan untuk usaha mikro dan kecil sejumlah 1 (satu) perseroan untuk setiap tahunnya dan dalam pendiriannya diberikan keringanan biaya terkait pendirian badan hukum.

\section{d. Perubahan Pernyataan Pendirian Perseroan Terbatas Perorangan}

Sebagaimana telah dijelaskan diatas, salah satu organ dalam perseroan terbatas adalah RUPS, dimana forum RUPS merupakan tempat dimana para pemegang saham mengambil suatau keputusan terkait perseroan terbatas. Dalam hal perseroan terbatas perseorangan RUPA digantikan dengan keputusan pemegang saham perseroan perorangan, hal ini diatur dalam Pasal 8 PP No.8/2021 yang mengatur mengenai perubahan pernyataan pendirian perseroan terbatas.

Cara perubahan pernyataan pendirian perseroan terbatas tidak jauh berbeda dengan penyataan pendirian perseroan terbatas, pemegang saham diminta untuk mengisi format isian perubahan pernyataan pendirian perseroan terbatas dalam bahasa Indonesia yang mana perubahan tersebut dapat dilakukan lebih dari 1 (satu) kali.

Pernyataan perubahan tersebut juga diajukan kepada Menteri Hukum dan Hak Asasi Manusia untuk mendapatkan sertifikat pernyataan perubahan dan berlaku sejak terbitnya sertifikat tersebut. Perseroan perorangan yang dinyatakan pailit berdasarkan putusan pengadilan tidak dapat dilakukan perubahan kecuali mendapat persetujuan dari kurator yang dilampirkan dalam pernyataan perubahan.

\section{e. Perubahan Status Perseroan Terbatas Perorangan menjadi Perseroan Terbatas.}

PP No.8/2021 mengatur bahwa perseroan perorangan harus mengubah status badan hukumnya menjadi perseroan terbatas pada umumnya jika pemegang saham menjadi lebih dari 1 (satu) orang atau sudah tidak memenuhi kriteria sebagai usaha mikro dan kecil. Perubahan tersebut harus dilakukan melalui notaris dengan dibuatnya akta dan didaftarkan kembali secara elektronik kepada Menteri Hukum dan Hak Asasi Manusia.

\section{f. Kewajiban Membuat Laporan Keuangan Untuk Perseroan Terbatas Perorangan.}

Berdasarkan Pasal 10 PP No.8/2021 perseroan perorangan diwajibkan membuat laporan keuangan yang dilaporkan kepada Menteri Hukum dan Hak Asasi Manusia dengan mengisi format isian penyampaian laporan keuangan dengan cara elektronik paling lambat 6 (enam) bulan setela akhir dari periode akuntansi berjalan.

Laporan keuangan tersebut paling tidak memuat laporan posisi keuangan, laba rugidan catatan atas laporan keuangan tahun berjalan. Menteri Hukun dan Hak Asasi Manusia akan menerbitkan bukti penerimaan pelaporan keuangan secara elektronik dan untuk perseroan perorangan yang tidak menyampaian laporan keuangan tersebut kan dikenai sanksi administratif berupa teguran tertulis, penghentian hak akses atas layan atau pencabutan status perseroan sebagai badna hukum.

\section{g. Pembubaran Perseroan Terbatas Perorangan.}

Pemegang saham perseroan terbatas perorangan dapat membubarkan perseroan dengan membuat keputusan pemegang saham yang dituangkan dalam pernyataan pembubaran dan dberitahukan secara elektronik kepada Menteri Hukum dan Hak Asasi Manusia.

Selain dengan keputusan pemegang saham, perseroan perorangan dapat bubar karena jangka waktunya telah berakhir, berdasarkan penetapan pengadilan perseroan tersebut dinyatakan bubar,dengan dicabutnya putusan pengadilan yang telah berkekuatan hukum tetap harta pailit perseroan perorangan tidak cukup membayar biaya kepailitan, harta pailit berada dalam keadaan insolvensi atau dicabutnya izin usaha sehingga mewajibkan perseroan perorangan melakukan likuidasi dan mengisi pernyataan pembubaran.

\section{Potensi Terjadinya Konflik Kepentingan dalam Pengurusan Perseroan Terbatas yang didirikan oleh satu orang}


Perbedaan antara perseroan terbatas perseorangan dengan perseroan terbatas yang didirikan oleh 2 (dua) orang atau lebih yakni dari cara pendiriannya perseroan terbatas perseorangan tidak memerlukan akta otentik yang dibuat dihadapan notaris yang konsekuensinya biaya pendirian pada perseroan terbatas perorangan lebih rendah, perubahan anggaran dasar pada perseroan terbatas biasa menggunakan RUPS sedangkan pada perseroan terbatas perorangan hanya menggunakan keputusan pemegang saham yang mepunyai kekuatan hukum yang sama seperti RUPS. Pada perseroan terbatas perorangan diwajibkan untuk melaporkan laporan keuangan tiap tahunnya kepada Menteri Hukum dan Hak Asasi Manusia sedangkan perseroan terbatas tidak perlu melaporkan keuangan tersebut. Perseroan terbatas perorangan hanya untuk kriteria usaha mikro dan kecil sedangkan perseroan terbatas biasa bisa didirikan untuk kriteria usaha apa saja.

Dalam perseroan terbatas biasa pun perseroan terbatas perorangan tidak terdapat perbedaan dalam organ perseroan, hal ini dapat dilihat jika menelaah UU Perseroan Terbatas, UU Cipta Kerja dan PP No.8/2021 tidak ada pengaturan yang merubah susnan organ dalam perseroan terbatas perorangan. Setiap pihak yang berkedudukan sebagai pemegang saham, direksi dan dewan komisaris dalam perseroan mempunyai potensi untuk menggunakan perseroan untuk kepentingan pribadinya yang biasanya disebut konflik kepentingan dan hal tersebut dilarang untuk dilakukan oleh perundang-undangan.

Direksi sebagai pengurus perseroan terbatas yang bewenang mewakili perseroan baik didalam maupun diluar pengadilan merupakan organ yang paling berpotensi mempunyai konflik kepentingan, oleh karena itu direksi dalam menjalankan tugasnya harus menjalankan dengan itikad baik dan oleh karena itu ia wajib menghindari konflik kepentingan dalam melaksanakan tugasnya. Setiap tindakan pengurusan yang mengadung konflik kepentingan dikategorikan sebagai tindakan itikad buruk karena tindakan tersebut melanggar kewajiban kepercayaan yang berarti dapat dipercaya dan jujur dan kewajiban menaati peraturan perundang-undangan.

Kewajiban anggota direksi untuk menghindari konflik kepentingan yakni tidak mempergunakan uang dan kekayaan perseroan untuk kepentingan pribadinya, ini merupakan suatau masalah tersendiri dalam perseroan perorangan, sebagaimana kita ketahui pelaku usaha mikro dan kecil kebanyakan tidak memahami akuntansi sederhana yang biasanya diterapkan dalam suatu usaha yang berbadan hukum, sehingga bisa saja dalam suatau perseroan terbatas perorangan yang dimana pemegang saham juga menjabat sebagai angggota direksi mencampurkan kekayaan perseroan dengan kekayaan pribadinya dikarenakan hanya mengetahui sistem keuangan yang sederhana yang biasanya dipakai saat ia menjalankan usaha secara perorangan dengan tidak berbadan hukum, konsekuensinya akan terletak pada pihak ketiga yang mengadakan suatu perikatan kepada perseroan perorangan tersebut, akan sangat sulit meminta pertanggungjawaban kepada perseroan perorangan tersebut jika terjadi suatu kerugian pada pihak ketiga atau bahkan perseroan perorangan bisa saja dijadikan alat untuk menghindari tanggung jawab oleh pelaku usaha yang memang dari awal mempunyai itikad buruk.

Apabila anggota direksi menggunakankekayaan perseroan untuk kepentingan pribadinya maka anggota direksi tersebut akan dikategorikan melakukan perbuatan melawan hukum sebagaimana diatur dalam Pasal 1365 BW dan atas dasar tersebut dapat dimintakan pertanggungjawaban secara perdata dan bahkan dapat diminta pertanggungjawaban secara pidana yang berdasar dengan penggelapan uang atau penipuan. Namun jika anggota direksi tersebut merupakan pemegang saham dalam perseroan perorangan hal ini juga masalah baru untuk pihak ketiga yang mengalami kerugian jika akan melaporkan secara pidana, maka pemegang saham tersebut akan lebih lama mengganti kerugiannya disebabkan ia tertahan atau dipenjara dan tidak ada anggota direksi atau pemegang saham lainnya yang akan menjelaskan pengurusan perseroan tersebut.

Tidak hanya mengenai konflik kepentingan terkait dengan kekayaan perseroan, konflik kepentingan karena menggunakan informasi perseroan untuk kepentingan pribadi punmerupakan suatu pelanggaran, hal ini lebih sulit lagi dikontrol jika pemegang saham merupakan anggota direksi yang melakukan pengurusan pada perseroan perorangan. 
Kosmik Hukum Vol. 21 No. 2 (2021): 115-123

E-ISSN: 2655-9242 | P-ISSN: 1411-9781

DOI: 10.30595/kosmikhukum.v21i2.10310

Menggunakan posisi sebagai direksi untuk memperoleh keuntungan seperti sogokan juga merupakan konflik kepentingan, namun hal itu baru akan terjadi jika pemegang saham dan anggota direksi merupakan orang yang berbeda.

Perhatian juga penulis taruh pada PP No.8/2021 yang tidak mengatur lebih spesifik mengenai dewan komisaris dalam suatu perseroan perorangan, dewan komisaris merupakan salah satu organ penting yang menjalankan pengawasan terhadap kegiatan perseroan. Hal ini menimbulkan pertanyaan apakah dalam perseroan terbatas peroangan diizinkan untuk tidak menunjuk seseorang untuk menjadi dewan komisaris. Jika hal tersebut dilakukan maka akan bertentangan dengan teori organ perseroan yang diatur dalam Pasal 1 angka 2 UU Perseroan Terbatas yang. Terlepas dari kriteria usaha mikro dan kecil, suatau usaha tetaplah harus dikelola dan diawasi dengan baik, jika tidak akan berpotensi menimbulkan kerugian kepada pihak lain yang mengadakan suatau hubungan hukum terhadap perseroan perorangan tersebut, maka sudah seharusnya ada pengaturan mengenai dewan komisaris untuk perseroan perorangan.

RUPS juga digantikan dengan keputusan pemegang saham, hal ini tentu saja sudah sewajarnya diatur dikarenakan konsep RUPS sudah tidak tepat lagi digunakan untuk perseroan perorangan. Dalam PP No.8/2021 diatur bahwa keputusan pemegang saham bisa digunakan untuk perubahan pernyataan pendirian dan pembubaran perseroan perorangan, namun bagaimana jika saat direksi ingin melakukan suatau perbuatan hukum yang sifatnya perlu persetujuan dari pemegang saham, apakah dapat menggunakan keputusan pemegang saham tersebut atau dengan surat jenis lainnya.

Berdasarkan UU Cipta Kerja pemegang saham perseroan perorangan tidak bertanggung jawab atas kerugian perseroan melebihi saham yang dimiliki, namun ketentuan tersebut tidak berlaku jika persyaratan perseroan sebagai badan hukum belum atau tidak terpenuhi, pemegang saham baik langsung ataupun tidak langsung dengan itikad buruk memanfatkan perseroan untuk kepentingan pribadi, pemegang saham yang bersangkutan terlibat dalam perbuatan melawan hukum yang dilakukan perseroan perorangan atau pemegang saham baik langsung maupun tidak langsung secara melawan hukum menggunakan kekayaan perseroan, yang mengakibatkan kekayaan perseroan menjadi tidak cukup untuk melunasi utang-utang perseroan.

Dalam hal perseroan perorangan, penulis berpendapat konflik kepentingan dalam suatu perseroan perorangan yang pemegang sahamnya juga menjabat sebagai satu-satunya anggota direksi besar potensinya untuk terjadi, mengingat mayoritas pelaku usaha mikro dan kecil seringkali dalam menjalankan usaha tidak memiliki pengelolaan keuangan yang baik dimana omset serta laba yang diterima perseroan perorangan langsung digunakan untuk kepentingan pribadi.

Hal tersebut sudah sewajarnya terjadi, sebab pelaku usaha mikro dan kecil kebanyakan lebih menyukai sistem yang sederhana dan mudah dimengerti, sehingga jikadijalankan oleh perseroan terbatas perorangan justru akan menjadi menyulitkan pihak yang merasa dirugikan oleh perseroan perorangan tersebut dalam meminta ganti rugi terhadap perseroan perorangan tersebut.

Hal ini tentu merupakan satu konflik kepentingan yang nyata, terlebih lagi dalam praktek akan terjadi ketidakpastian hukum terkait dengan pertanggungjawaban terbatas (limitasi tanggung jawab) dalam pelaksanaan kegiatan usaha perseroan terbatas. Dengan kata lain, akan terjadi ketidakpastian hukum mengenai pemisahan tanggung jawab orang perorangan tersebut dengan badan hukum perseroan terbatas yang didirikan tersebut.

\section{Penutup}

Pendirian perseroan terbatas perseorangan memberikan kemudahan bagi pelaku usaha yang ingin mempunyai usaha berbadan hukum namun terbatas untuk kriteria usaha mikro dan kecil. Bahkan pendiriannya tidak perlu menggunakan akta notaris, hanya pernyataan pendirian saja dan bahkan perubahan dan pembubaran perseroan perorangan dapat dilakukan dengan pernyataan yang harus didaftarkan ke Menteri Hukum dan Hak Asasi Manusia. Namun 
mengingat dalam suatu perseroan terbatas perorangan ada pemisahan harta antara kekayaan pribadi pemegang saham dan kekayaan perseroan perorangan yang ia dirikan, maka jika dia menjabat juga sebagai satu-satunya direksi dalam perseroan terbatas perorangan potensi untuk terjadi konflik kepentingan dalam perseroan perorangan tersebut lebih besar dari pada dalam perseroan terbatas yang ddirikan secara biasa. Telebih lagi dewan komisaris yang merupakan organ yang melakukan pengawasan dalan suatu perseroan terbatas tidak diatur lebh spesifik mengenai apakah harus ada dewan komisaris dalam perseroan perorangan dan jika iya apa saja kewenangan dari dewan komisaris tersebut. Menurut penulis pendirian perseroan terbatas perorangan untuk mengakomodir usaha mikro dan kecil terlalu memaksa, akan jauh lebih baik jika commanditaire venootshcap atau baisa disebut CV yang diatur ulang agar bisa mengakomodir pelaku usaha perorangan untuk kriteria usaha kecil dan mikro, hal ini penulis rasa lebih tepat karena pertanggung jawaban sekutu aktif dalam CV sampai keharta pribadi, sehingga pihak ketiga yang mengalami kerugian yang disebabkan suatu usaha CV tidak kesulitan ketika akan meminta ganti rugi.

\section{Daftar Pustaka}

Budiyono, Tri. Hukum Perusahaan. Salatiga, Griya Media, 2011.

Harahap, M. Yahya. Hukum Perseroan Terbatas. Jakarta: Sinar Grafika, 2009.

Hernoko, Agus Yudha. Hukum Perjanjian. Jakarta: Prenada Media Group, 2014.

Ibrahim, Johnny. Teori dan Metodologi Penelitian Hukum Normatif. Malang: Bayumedia, 2008.

Kitab Undang-Undang Hukum Perdata

Marzuki, Peter Mahmud. Penelitian Hukum. Jakarta, Prenada Media Group, 2016.

Nadapdap, Binoto. Hukum Perseroan Terbatas. Jakarta: Jala Permata Aksara, 2009.

Peraturan Pemerintah Nomor 8 Tahun 2021 tentang Modal Dasar Perseroan Serta Pendaftaran Pendirian, Perubahan Dan Pembubbaran Perseroan Yang Memenuhi Kriteria Untuk Usaha Mikro Dan Kecil

Rastuti, Tuti. Seluk Beluk Perusahaan \& Hukum Perusahaan. Bandung, Refika Aditama, 2015.

Subekti. Pokok-Pokok Hukum Perdata. Jakarta: Intermasa, 2008.

Undang-Undang Nomor 11 tahun 2020 tentang Cipta Kerja.

Undang-Undang Nomor 20 Tahun 2008 tentang Usaha Mikro, Kecil dan Menengah.

Undang-Undang Nomor 40 Tahun 2007 tentang Perseroan Terbatas. 